UDC 65.014.1:016.1

DOI: https://doi.org/10.32782/2224-6282/170-7

\author{
Vlasenko Valentyn \\ Candidate of Economic Sciences, Associate Professor, \\ Higher Educational Institution of Ukoopspilka \\ «Poltava University of Economics and Trade» \\ ORCID: https://orcid.org/0000-0003-3892-9512
}

Власенко В. А. кандидат економічних наук, доцент, Вищий навчальний заклад Укоопспілки «Полтавський університет економіки і торгівлі»

\title{
PRINCIPLED APPROACH TO THE FORMATION OF ANTI-CRISIS PROGRAM OF ENTERPRISE DEVELOPMENT IN THE CONDITIONS OF TRANSFORMATION PROCESSES
}

The methodological and practical recommendations for the formation and implementations of an effective anti-crisis development program at the enterprise in the market conditions are substantiated. For this purpose the author's version of the structure of the anti-crisis development program at the enterprise in separate sections is recommended. The stages of the formation mechanism of crisis management at the enterprise in the conditions of economic crisis that allowed systematizing actions of separate subjects of anti-crisis process are considered. The content of the principal version of the anti-crisis development program at the enterprise for the perspective period is disclosed. As a result of the research, the separate tasks facing the employees are proposed, the actions and measures necessary for their implementation are singled out, the responsible persons, the terms of the program implementation and the necessary amount of financial resources are determined.

Keywords: crisis, the crisis processes, the crisis phenomena, financial crisis, the plan of anti-crisis measures, anti-crisis development program at the enterprise, the team of anti-crisis managers, anti-crisis process.

JEL classification: C12, C18, G33, H12

\section{ПРИНЦИПОВИЙ ПІДХІД ДО ФОРМУВАННЯ АНТИКРИЗИСНОЇ ПРОГРАМИ РОЗВИТКУ ПІДПРИЕМСТВА В УМОВАХ ТРАНСФОРМАЦИЙНИХ ПРОЦЕСІВ}

У роботі обтрунтовано методологічні та розглянуто прикладні рекомендащії до формування та реалізаціі ефективної антикризової програми розвитку підриємства у ринкових умовах господарювання. Незважаючи на наявність окремих пропозицій щุодо розробки антикризової програми розвитку підприємства, иілісне розуміння їі структури та документальний супровід викликають особливий інтерес. 3 иією метою рекомендовано авторський варіант структури антикризової програми розвитку підприємства за окремими розділами. Вмежах системного підходу розглянуто дії команди антикризових менеджерів підприємства у разі розгортання фінансової кризи, щцо включають: загальну характеристику стану кризи розвитку підприємства та фінансової кризи; визначення окремих иільових параметрів антикризового процесу; встановлення часових та ресурсних обмежень антикризового процесу; визначення переліку планових антикризових заходів; формування бюджету витрачання коштів на реалізацію програми; розробка фінансового плану діяльності підприємства. Розглянуто етапи формування механізму антикризового управління підприємством в умовах економічної кризи, щчо дозволило систематизувати дії окремих суб'єктів антикризового прочесу. Під час реалізації механізму антикризового управління підприємством рекомендовано проводити діагностику кризових явищ $i$ загрози банкрутства; визначати мету $i$ завдання впровадження антикризових заходів; формувати відповідний склад команди антикризових менеджерів; оцінювати обмеження антикризового процесу та ресурсний потенціал підприємства; розробляти та впроваджувати антикризову програму розвитку підприємства; приймати коригувальні заходи. Розкрито зміст принципового варіанту антикризової програми розвитку підприємства на перспективний період. У результаті дослідження запропоновано окремі завдання, щчо стоять перед прачівниками, виокремлено дії та заходи, щзо необхідні для їх виконання, визначено відповідальних осіб, строки виконання програми та необхідний обсяг фінансових ресурсів. Завдяки застосуванню принципового підходу було систематизовано окремі антикризові заходи, щзо необхідні для успішної реалізації антикризової програми розвитку підприємства.

Ключові слова: криза, кризові процеси, кризові явища, фінансова криза, план антикризових заходів, антикризова програма розвитку підприємства, команда антикризових менеджерів, антикризовий прочес.

Formulation of the problem. In any society as a whole socio-economic system, its individual areas or links from time to time there are crisis phenomena that threaten the existence of the system itself. In Ukraine, with the transition to the market, the conditions for disruption of enterprises have objectively developed. Despite the fact that companies are gradually emerging from the crisis, this process needs to be accelerated. The main way of survival of the enterprise in such conditions is anti-crisis management, which should be based on timely diagnosis of the level and causes of the crisis and the implementation of adequate anti-crisis development programs.

The urgency of the study of this issue is due to the fact that current trends in the national economy require the formation and implementation at the level of individual economic entities effective anti-crisis development 
programs, as they will determine the direction of each enterprise out of crisis and avoid potential bankruptcy.

Analysis of recent research and publications. The question of studying the mechanisms of overcoming the crisis of economic entities and crisis management is the attention of many scientists, among which should be singled out Blank I.O., Harvard J., Irtyshcheva I., Karaim M.M., Levchenko Yu.G., Ligonenko L.O., R. Lis, Mechlap F., Minakova S., Semenov G.A., Shtangret A.M., Sukhomlin L.E., Van Horn J.K., Vasylenko V.O., Yaroshevska O.V. and others $[1 ; 2 ; 4 ; 5 ; 9 ; 10]$.

At the same time, paying tribute to the scientific heritage of scientists, it should be recognized that the development of an effective anti-crisis program at enterprises, together with its documentary support and individual anti-crisis measures in the context of the deployment of crisis processes, continues to be a debatable, practically significant and completely unsolved scientific task that requires a thorough scientific research.

The purpose of the article. The purpose of the study is to substantiate the methodological and consideration of the applied principles of formation and implementation of the anti-crisis program of enterprise development in the conditions of market transformations.

In accordance with the purpose of the study, the author's version of the anti-crisis program of enterprise development for the long term was developed and some anti-crisis measures during its implementation were proposed.

Formulation of the main material. In the science of management and finance, there is no single approach to understanding the essence of the anti-crisis program of enterprise development. In particular, there is an opinion that the anti-crisis program (plan of anti-crisis measures) is one of the forms of practical implementation of the financial strategy of the enterprise, namely the instrument of anti-crisis financial management policy [8, p. 117].

Leading Ukrainian scientists in the field of crisis management note that the anti-crisis development program should be developed on the basis of a detailed analysis of the financial condition of the enterprise, determining the depth of the financial crisis and the factors that led to its occurrence $[5$, p. $61-62 ; 7$, p. 74$]$. This program should be a detailed set of anti-crisis measures that will be implemented in practice, and its content and structure should be determined by the results of the diagnosis, the purpose of crisis management, its existing limitations [3, p. 204].

For these reasons, the anti-crisis program of enterprise development should be a special internal document, which will systematically list the main activities planned to be carried out within its structural units and functional services to achieve the goal - to bring the enterprise out of crisis.

On the other hand, the internal structure of the anticrisis program of enterprise development does not require special formalization, as it will be determined by the stage of the financial crisis and the essence of the measures envisaged for implementation [4, p. 68].

Finally, at the strategic level of the enterprise, its top management should consider and approve the approximate structure of the anti-crisis development program, which may become part of a long-term development plan for the main areas of economic activity. At the tactical level, this program should be taken into account by employees of structural units of the enterprise and unquestioningly implemented in terms of appropriate anti-crisis measures.
In accordance with the principles of a systematic approach, in the event of a financial crisis, the teams of anti-crisis managers (rehabilitation managers, financial managers, financial analysts, etc.) should be formed at the enterprise, which will be responsible for developing an anti-crisis development program.

In our opinion, the recommended author's version of the structure of the anti-crisis development program at the enterprise should include six separate sections:

1. General characteristics of the crisis of enterprise development and financial crisis. At the same time, the team of anti-crisis managers must identify the main causes that led to the crisis and consider the problems that need to be addressed.

2. Determination of individual target parameters of the anti-crisis process. This involves a qualitative definition of the target state of the enterprise and its quantitative characteristics in the form of a certain system of indicators. The set target parameters should be further used to monitor the implementation of the anti-crisis development program and make it possible to determine the degree of achievement of the set goals.

3. Establishment of time and resource constraints of the anti-crisis process. It should be noted that all existing restrictions should be carefully analyzed by the teams of anti-crisis managers depending on the degree of their impact on the company.

4. Determining the list of planned anti-crisis measures. In addition to a detailed list of crisis measures, the teams of anti-crisis managers need to make a detailed schedule for the implementation of each of them.

5. Formation of the budget of expenditure of funds for the implementation of the anti-crisis development program. This will identify planned anti-crisis measures that require additional funding.

6. Development of the financial plan of activity of the enterprise for the period of realization of the anticrisis program of its development. However, the teams of anti-crisis managers will also need to develop a plan for servicing and repaying individual debts.

In the process of forming an anti-crisis program of enterprise development, the teams of anti-crisis managers must develop the mechanism of crisis management.

In the most general definition, the mechanism is understood as the internal structure, the system of something, as well as the set of states and processes that make up a phenomenon [6, p. 22].

Representatives of the Ukrainian scientific school believe that the mechanism of crisis management should be understood as a set of tools and methods of influencing the object of management - crisis phenomena [2, p. 39]. The mechanism of crisis management in the economic system is a set of conceptual, methodological and software tools that allow to model options for making decisions; develop tools for their analysis and implementation, which increases their validity and reduces the risk of implementation [10, p. 53].

It should be noted that the main principles on which the mechanism of crisis management of the enterprise should be based are the following: reliance on anticrisis consciousness of staff, understanding the negative consequences and deepening of the crisis for all subjects of the anti-crisis process; anti-crisis motivation, the essence of which is the predominant use of motivational 
tools aimed at solving crisis problems; multivariate development of possible anti-crisis procedures taking into account the uncertainty factor; realism, when in assessing the crisis situation must be based on objective reality $[9$, p. 162].

Accordingly, the teams of anti-crisis managers need to develop the mechanism of crisis management at the enterprise in an economic crisis with the allocation of the main stages of its formation. This will allow systematizing the actions of individual subjects of the anti-crisis process.

In our opinion, an effective mechanism of crisis management at the enterprise in an economic crisis should be formed in stages and provide the following sequence of actions:

1. Diagnosis of crisis phenomena and the threat of bankruptcy. At this stage it is necessary to carry out a comprehensive analysis of the results of economic and financial activities and property status of the enterprise, as well as qualitative indicators of its activities.

2. Defining the goals and objectives of the implementation of anti-crisis measures. The results of the diagnosis will make it possible to determine the depth of the crisis that has gripped of the enterprise, and therefore to determine the purpose and objectives of the crisis management mechanism. Depending on the depth of the crisis, such tasks may be: bringing the company out of legal bankruptcy; prevention of bankruptcy; localization of crisis phenomena; financial stabilization; prevention of recurrence of the crisis [1, p. 247].
3. Formation of the appropriate team of anti-crisis managers. This involves identification of subjects of anti-crisis activities that will take responsibility for the development and implementation of anti-crisis procedures and implementation of anti-crisis program of enterprise development. It should be noted that problematic, according to the author, is the development of measures to bring the enterprise out of crisis by the same person (or team of managers), whose activities or inactions led to its emergence. Therefore, the successful normalization of activities is possible with the replacement of senior management or by involving in the development of anti-crisis program for the development of young middle management. Since the effectiveness of this work is largely determined by the experience and professionalism of the invited specialists, their search and involvement in cooperation is a necessary step in the formation of the mechanism of crisis management at the enterprise.

4. Assessment of the limitations of the anti-crisis process. It should be noted that the time constraints of anticrisis procedures are determined by the intensity of the crisis and the existing bankruptcy proceedings.

5. Assessment of the resource potential of the enterprise in the process of crisis management. Assessing the resource potential of the enterprise in the process of crisis management, it is necessary to pay attention to such characteristics as: adequacy of resources; their flexibility and adaptability; prospects of resource potential.

Table 1

Recommended anti-crisis program of enterprise development for the perspective period

\begin{tabular}{|c|c|c|c|c|}
\hline $\begin{array}{c}\text { Tasks facing } \\
\text { employees }\end{array}$ & $\begin{array}{c}\text { Actions and measures necessary for their } \\
\text { implementation }\end{array}$ & Responsible performers & Dead-lines & $\begin{array}{l}\text { Required } \\
\text { resources }\end{array}$ \\
\hline $\begin{array}{l}\text { 1. Introduction } \\
\text { of a modern system } \\
\text { of anti-crisis financial } \\
\text { management }\end{array}$ & $\begin{array}{l}\text { Formation and adoption of cost estimates } \\
\text { for the implementation of financial policy } \\
\text { of the enterprise. }\end{array}$ & $\begin{array}{l}\text { General Director, } \\
\text { Head of Finance } \\
\text { Department, } \\
\text { Chief Accountant }\end{array}$ & 5-6 weeks & $\begin{array}{l}8-10 \% \text { of the total } \\
\text { budget estimate }\end{array}$ \\
\hline $\begin{array}{l}\text { 2. Formation of modern } \\
\text { organizational support } \\
\text { of the anti-crisis } \\
\text { financial management } \\
\text { system }\end{array}$ & $\begin{array}{l}\text { View the staffing schedule of the enterprise. } \\
\text { View job descriptions for functional } \\
\text { performers. } \\
\text { Staff training. } \\
\text { Changing the organizational structure } \\
\text { of management at the enterprise. }\end{array}$ & $\begin{array}{l}\text { Head of Human } \\
\text { Resources, Head } \\
\text { of Finance Department, } \\
\text { General Director }\end{array}$ & $\begin{array}{l}1-2 \text { weeks } \\
(2 \text { times a } \\
\text { year) }\end{array}$ & $\begin{array}{l}5-7 \% \text { of the total } \\
\text { budget estimate }\end{array}$ \\
\hline $\begin{array}{l}\text { 3. Revival } \\
\text { of business activity } \\
\text { of the enterprise }\end{array}$ & $\begin{array}{l}\text { Expansion of product markets. Review } \\
\text { of the pricing policy of the enterprise. } \\
\text { Providing discounts to potential buyers. } \\
\text { Participation in the implementation of joint } \\
\text { investment projects. } \\
\text { Participation in the work of commodity } \\
\text { exchanges. }\end{array}$ & $\begin{array}{l}\text { Financial Manager, } \\
\text { Head of Finance } \\
\text { Department, Chief } \\
\text { Accountant, General } \\
\text { Director }\end{array}$ & $2-3$ months & $\begin{array}{l}17-20 \% \text { of the } \\
\text { budget of the anti- } \\
\text { crisis development } \\
\text { program }\end{array}$ \\
\hline $\begin{array}{l}\text { 4. Restoration } \\
\text { of solvency and } \\
\text { liquidity of the } \\
\text { enterprise }\end{array}$ & $\begin{array}{l}\text { Refusal to use illiquid assets. } \\
\text { Active work with debtors to restructure } \\
\text { their debt. } \\
\text { Application of the mechanism of factoring } \\
\text { operations. } \\
\text { Review of marketing, sales and assortment } \\
\text { policy of the enterprise. }\end{array}$ & $\begin{array}{l}\text { Financial Manager, } \\
\text { Head of Finance } \\
\text { Department, Chief } \\
\text { Accountant, Head } \\
\text { of Marketing Department, } \\
\text { General Director }\end{array}$ & $3-4$ months & $\begin{array}{l}20 \% \text { of the budget } \\
\text { of the anti-crisis } \\
\text { development } \\
\text { program }\end{array}$ \\
\hline $\begin{array}{l}\text { 5. Formalization } \\
\text { of anti-crisis measures }\end{array}$ & $\begin{array}{l}\text { Adoption of an anti-crisis development } \\
\text { program. } \\
\text { Empowerment of the financial manager for } \\
\text { anti-crisis issues of enterprise development. } \\
\text { Advanced training in crisis management. } \\
\text { Referrals for training specialists. }\end{array}$ & $\begin{array}{l}\text { Financial Manager, } \\
\text { Head of Human } \\
\text { Resources, General } \\
\text { Director }\end{array}$ & 1 week & $\begin{array}{l}4-5 \% \text { of the budget } \\
\text { of the anti-crisis } \\
\text { development } \\
\text { program }\end{array}$ \\
\hline
\end{tabular}

Source: developed by the author 
6. Development of the anti-crisis program of enterprise development. The author proposes to develop a functional part of the anti-crisis program of enterprise development $[11$, p. 125]. This program will be a detailed set of anticrisis measures to be implemented in practice, and its content and structure should be determined by the results of the diagnosis, the purpose of crisis management and its time and resource constraints.

The recommended author's version of the anti-crisis program of enterprise development for the perspective period is shown in Table 1.

7. Implementation of the anti-crisis program of enterprise development and control over its implementation.

8. Taking corrective measures. Adoption of corrective measures (if necessary), as well as the development and implementation of preventive measures to prevent a recurrence of the economic crisis in the enterprise in the future.

It is necessary to emphasize that in the effective anticrisis program of enterprise development in the conditions of financial and economic crisis the tasks facing employees should be detailed, actions and measures necessary for their performance should be determined, responsible persons should be established, terms of its realization and necessary resources should be determined. This will help streamline certain anti-crisis measures at the level of structural units of the enterprise and ensure its competitive advantages in the long run.

There is no doubt that the proposed anti-crisis measures within the anti-crisis development program are an effective tool of modern financial policy of the enterprise aimed at implementing a long-term strategy for its development.

It is worth noting that the given list of anti-crisis actions and measures within the anti-crisis program of enterprise development is not final, as there is no single recipe for survival and revival in the context of the financial crisis. The defined tools should be considered only as a generalized list of typical anti-crisis measures.

Conclusions. Thus, the practical implementation of the anti-crisis development program at Ukrainian enterprises during the market transformation will unite the main directions of anti-crisis financial management policy, create an effective mechanism for neutralizing financial risks and assess the development potential of each business entity depending on changing environmental conditions. The proposed sequence of formation of an effective mechanism of crisis management will contribute to the implementation of anti-crisis program of enterprise development, strengthening its competitive advantages to overcome the effects of the economic crisis and enter a new trajectory of economic growth.

Promising directions of further scientific research are the implementation of individual anti-crisis development programs at the enterprises based on an integrated approach. The study of key elements of the mechanism of crisis management of the enterprise involves the application of a systematic approach and the implementation of further research in this area.

\section{References:}

1. Blank I.A. (2003) Upravlenye fynansovoy stabylyzatsyey predpryyatyya : uchebnyy kurs [Management of financial stabilization of the enterprise : Training course]. Kyiv: Nyka-Tsentr, Él'ha. (in Russian)

2. Irtyshcheva I., Minakova S. (2015) Obhruntuvannya kontseptsiyi stratehichnoyi prohramy v antykryzovomu upravlinni [Substantiation of the concept of strategic program in crisis management]. Ekonomist, no. 11, pp. 38-40.

3. Kovbatyuk M.V., Shklyar V.V. (2016) Otsinyuvannya efektyvnosti zakhodiv antykryzovoho menedzhmentu pidpryyemstv transportnoyi haluzi [Evaluation of the effectiveness of anti-crisis management measures for transport enterprises]. Aktual'ni problemy ekonomiky, no. 5, pp. 201-210.

4. Levchenko Yu.G., Kiver A.V. (2016) Rozrobka ta obgruntuvannya antykryzovykh zakhodiv na pidpryyemstvi [Development and justification of anti-crisis measures at the enterprise]. Formuvannya rynkovykh vidnosyn v Ukrayini, no. 5, pp. 66-70.

5. Ligonenko L.O. (2001) Antykryzove upravlinnya pidpryyemstvom: teoretyko-metodolohichni zasady ta praktychnyy instrumentariy: monohrafiya [Anti-crisis management of the enterprise: theoretical and methodological principles and practical tools: Monograph]. Kyiv: Kyyivs'kyy natsional'nyy torhovel'no-ekonomichnyy universytet. (in Ukrainian)

6. Markina I.A., Bilovol R.I., Vlasenko V.A. (2013) Menedzhment orhanizatsiyi: navchal'nyy posibnyk [Management of the organization: Textbook]. Kyiv: Tsentr uchbovoyi literatury. (in Ukrainian)

7. Pushkar A.I., Trided A.N., Kolos A.L. (2001) Antykryzysnoe upravlenye: modely, stratehyy, mekhanyzmy : monohrafyya [Anticrisis management: models, strategies, mechanisms : Monograph]. Kharkov: Obshchestvo s ogranichennoy otvetstvennost'yu «Model' Vselennoy». (in Russian)

8. Ryakhovskaya A.N., Kovan S.E. (2016) Antykryzysnoe upravlenye kak osnova formyrovanyya mekhanyzma ustoychyvoho razvytyya byznesa : monohrafyya [Anti-crisis management as a basis for the formation of a mechanism for sustainable business development: Monograph]. Moscow: Svaroh. (in Russian)

9. Semenov G.A., Yaroshevska O.V. (2010) Stratehichna prohrama antykryzovoho upravlinnya pidpryyemstvom [Strategic program of crisis management of the enterprise]. Derzhava ta rehiony, no. 3, pp. 159-166.

10. Shtangret A.M., Karaim M.M., Sukhimlin L.E. (2016) Antykryzovyy mekhanizm upravlinnya ekonomichnoyu bezpekoyu pidpryyemstva [Anti-crisis management mechanism of economic security of the enterprise]. Formuvannya rynkovykh vidnosyn $v$ Ukrayini, no. 3, pp. 51-55.

11. Vlasenko V. A. (2019) Realizatsiya antykryzovoyi prohramy rozvytku torhovel'noho pidpryyemstva v umovakh transformatsiyi natsional'noyi ekonomiky [Implementation of anti-crisis program for the development of trade enterprise in the transformation of the national economy]. Proceedings of the Merezhevyy biznes: stanovlennya, problemy, innovatsiyi: materialy IX Mizhnarodnoyi naukovopraktychnoyi internet-konferentsiyi (Ukraine, Poltava, April 18-19, 2019). Poltava: PUET, pp. 124-127.

\section{Список використаних джерел:}

1. Бланк И.А. Управление финансовой стабилизацией предприятия : учеб. курс. Киев : Ника-Центр, Эльга, 2003. 496 с.

2. Іртищева І., Мінакова С. Обгрунтування концепції стратегічної програми в антикризовому управлінні. Eкономіст. 2015. № 11. C. $38-40$. 
3. Ковбатюк М.В., Шкляр В.В. Оцінювання ефективності заходів антикризового менеджменту підприємств транспортної галузі. Актуальні проблеми економіки. 2016. № 5. С. 201-210.

4. Левченко Ю.Г., Ківер А.В. Розробка та обгрунтування антикризових заходів на підприємстві. Формування ринкових відносин в Україні. 2016. № 5. С. 66-70.

5. Лігоненко Л.О. Антикризове управління підприємством: теоретико-методологічні засади та практичний інструментарій : монографія. Київ : Київ. нац. торг.-екон. ун-т, 2001. 580 с.

6. Маркіна І.А., Біловол Р.І., Власенко В.А. Менеджмент організації : навч. посібник. Київ : Центр учбової літератури, 2013. 248 c.

7. Пушкарь А.И. Тридед А.Н., Колос А.Л. Антикризисное управление: модели, стратегии, механизмы : монография. Харьков : ООО «Модель Вселенной», 2001. 452 с.

8. Ряховская А.Н., Кован С.Е. Антикризисное управление как основа формирования механизма устойчивого развития бизнеса : монография. Москва : Сварог, 2016. 169 с.

9. Семенов Г.А., Ярошевська О.В. Стратегічна програма антикризового управління підприємством. Держава та регіони. 2010. № 3. C. 159-166.

10. Штангрет А.М., Караїм М.М., Сухимлин Л.С. Антикризовий механізм управління економічною безпекою підприємства. Формування ринкових відносин в Украӥні. 2016. № 3. С. 51-55.

11. Власенко В.А. Реалізація антикризової програми розвитку торговельного підприємства в умовах трансформації національної економіки. Мережевий бізнес: становлення, проблеми, інновації : матеріали IX Міжнародної науково-практичної інтернет-конференції (18-19 квітня 2019 р., м. Полтава). Полтава : ПУЕТ, 2019. С. 124-127. 